\title{
FAKTOR-FAKTOR YANG MEMPENGARUHI LABA BERSIH PADA PERUSAHAAN INDUSTRI ROKOK YANG TERDAFTAR DI BEI
}

\author{
Shella Putri Yulistiani ${ }^{1}$ \\ Gusganda Suria Manda²
Fakulras Ekonomi Universitas Singaperbangsa Karawang, Jawa Barat, Indonesia ${ }^{1,2}$
Email : 1610631030256@student.unsika.ac.id ${ }^{1}$
gusganda.suriamanda@fe.unsika.ac.id ${ }^{2}$

\begin{abstract}
This study aims to determine the effect of Production Costs, Operational Costs, and Sales on Net Profits for the 2009-2019 period. Cigarette companies that have gone public are one of the companies that have been able to operate for a relatively long period of time. Go public cigarette companies that are listed on the Indonesia Stock Exchange (IDX) have been able to generate considerable foreign exchange for the country and are also able to absorb a large number of workers, so as to increase national income. The level of how much the development of a company can be seen from the profits generated in carrying out its operating activities. If the company's goals are achieved, the company's survival can be maintained and able to compete with other companies. Testing the hypothesis of this study using Multiple Linear Regression Analysis. This research was conducted at the Cigarette Industry Company in the period 2009-2019. The population was 5 cigarette companies and the sample used was 3 cigarette companies. The sample technique used is purposive sampling technique. The results of this study indicate that production costs have a significant and significant effect on net income. Operating costs have no effect on net income. And sales have an effect on net income..
\end{abstract}

Keywords: Production Costs; Operating Costs; Sales; Net Income

\begin{abstract}
ABSTRAK
Penelitian ini bertujuan untuk mengetahui pengaruh Biaya Produksi, Biaya Operasional, dan Penjualan terhadap Laba Bersih periode 2009-2019. Perusahaan-perusahaan rokok yang telah go public merupakan salah satu perusahaan yang telah mampu beroperasi dalam jangka waktu yang relatif lama. Perusahaan rokok go public yang terdaftar di Bursa Efek Indonesia (BEI) telah mampu menghasilkan devisa yang cukup besar bagi Negara dan juga mampu menyerap tenaga kerja yang cukup banyak, sehingga dapat meningkatkan pendapatan nasional. Perusahaan didirikan bertujuan untuk mendapatkan laba, memaksimalkan nilai saham, meningkatkan volume penjualan dan meningkatkan kesejahteraan pemegang saham. Tingkat seberapa besarnya perkembangan suatu perusahaan dapat dilihat dari laba yang dihasilkan dalam menjalankan kegiatan operasinya. Jika tujuan perusahaan itu tercapai maka kelangsungan hidup perusahaan mampu dipertahankan dan mampu bersaing dengan perusahaan lain.Pengujian hipotesis penelitian ini menggunakan Analisis Regresi Linier Berganda. Penelitian ini dilakukan pada Perusahaan Industri Rokok pada periode tahun 2009-2019. Populasi sebanyak 5 perusahaan rokok dan sampel yang digunakan sebanyak 3 perusahaan rokok. Teknik sampel yang digunakan yaitu teknik purposive sampling. Hasil penelitian ini menunjukan bahwa biaya produksi berpengaruh dan signifikan terhadap laba bersih. Biaya operasional tidak berpengaruh terhadap laba bersih. Dan penjualan berpengaruh terhadap Laba Bersih.
\end{abstract}

Kata kunci: Biaya Produksi; Biaya Operasional; Penjualan; Laba Bersih. 


\section{PENDAHULUAN}

Perusahaan-perusahaan rokok yang telah go public merupakan salah satu perusahaan yang telah mampu beroperasi dalam jangka waktu yang relatif lama. Perusahaan rokok go public yang terdaftar di Bursa Efek Indonesia (BEI) telah mampu menghasilkan devisa yang cukup besar bagi Negara dan juga mampu menyerap tenaga kerja yang cukup banyak, sehingga dapat meningkatkan pendapatan nasional. Perusahaan didirikan bertujuan untuk mendapatkan laba, memaksimalkan nilai saham, meningkatkan volume penjualan dan meningkatkan kesejahteraan pemegang saham. Tingkat seberapa besarnya perkembangan suatu perusahaan dapat dilihat dari laba yang dihasilkan dalam menjalankan kegiatan operasinya. Jika tujuan perusahaan itu tercapai maka kelangsungan hidup perusahaan mampu dipertahankan dan mampu bersaing dengan perusahaan lain.

Fenomena yang terjadi adalah kebijakan cukai atau pajak atas rokok merupakan faktor terbesar yang menghambat pertumbuhan industri hasil tembakau dalam lima tahun terakhir. Industri padat karya ini mengalami kemunduran sejak roadmap industri hasil tembakau intensif diberlakukan pada 2009 melalui kebijakan kenaikan cukai bertahap hampir setiap tahun. Dengan adanya kenaikan cukai produsen merupakan salah satu pihak yang mendapat kesulitan dan kerugian . Bagi perusahaan atau pabrik pengolah bahan mentah atau bahan setengah jadi menjadi barang bernilai ekonomi, maka masalah kenaikan harga berhubungan dengan biaya produksi. Industri selalu mengendalikan bahwa jika rokok dikendalikan maka konsumsinya akan turun dan menyebabkan penurunan produksi yang kemudian akan menimbulkan kerugian kepada industri 
rokok. Jika sudah rugi industri akan dengan terpaksa harus mengurangi biaya produksi yang salah satunya adalah dengan melakukan efisiensi tenaga kerja dan memicu terjadinya PHK massal. Sehingga negara juga akan merugi karena setoran pajak dan cukai industri rokok akan berkurang yang berarti pemasukkan negara juga berkurang. Berdasarkan paparan diatas diagram dibawah ini akan menyajikan data perkembangan laba bersih pada perusahaan manufaktur sub rokok yang terdaftar di BEI menggunakan data tahunan 2009-2019.

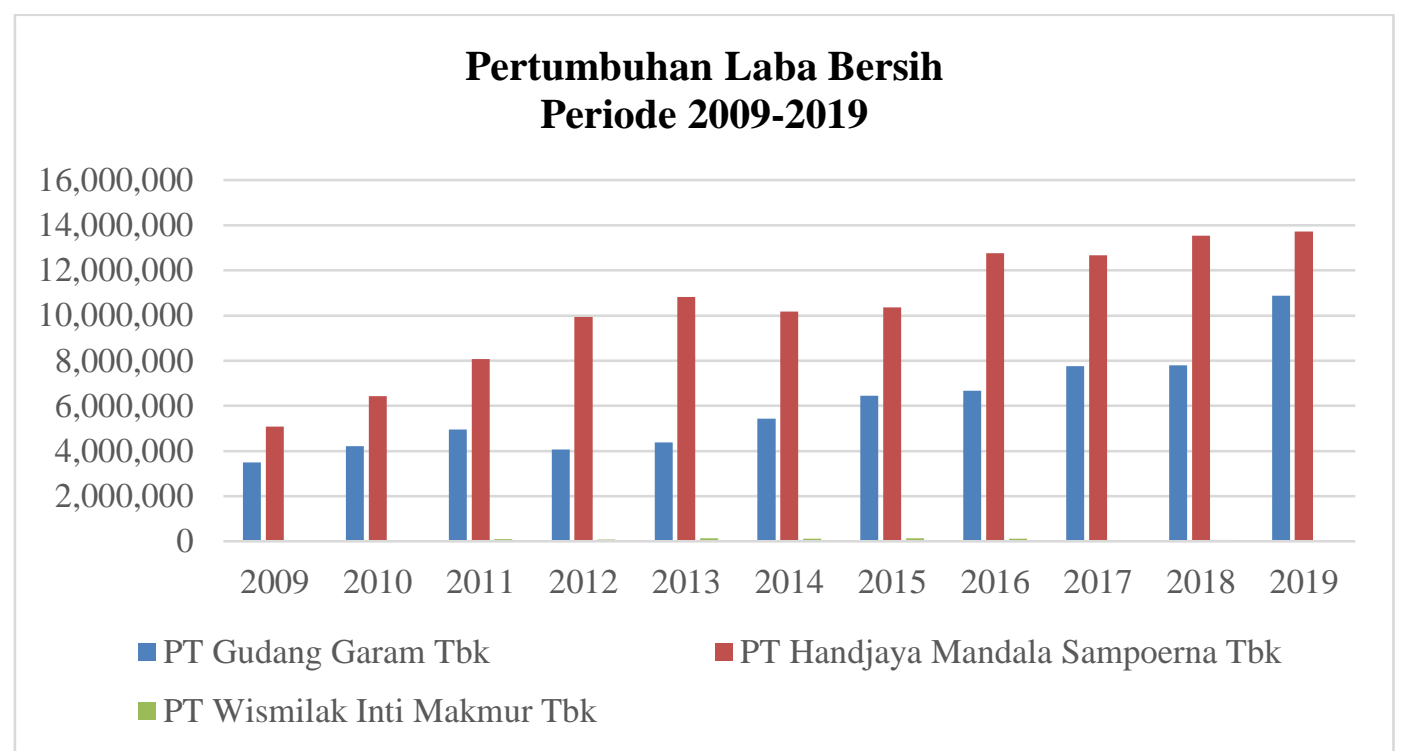

Sumber: www.idx.co.id, data diolah peneliti 2020

Diagram 1.

Pertumbuhan Laba Bersih Periode 2009-2019

Berdasarkan diagram 1 dinyatakan bahwa rata-rata laba bersih perusahaan mengalami fluktuatif dan cenderung naik. Hal ini berdampak positif terhadap perusahaan sehingga dapat dinilai bahwa kinerja keuangan perusahaan tersebut meningkat. Akan tetapi pada perusahaan Wismilak Inti Makmur Tbk sudah beberapa kali mengalami penurunan laba. Penurunan laba yang cukup signifikan pada tahun 2017 sebesar 62\%. Hal ini terjadi karena adanya penurunan volume penjualan yang dialami oleh perusahaan tersebut. 
Terdapat beberapa faktor yang mempengaruhi laba bersih suatu perusahaan diantaranya Biaya Produksi, Biaya Operasional dan Penjualan. Beberapa penelitian terdahulu yang dilakukan oleh (Putra, 2018), (Susilawati, 2019), (Ferliyanti \& Rostiati, 2019) menggunakan variabel biaya produksi, biaya operasional dan penjualan sebagai mediasi untuk melihat laba bersih perusahaan dan kinerja perusahaan.

Menurut (Horngren, 2008) biaya adalah sumber daya yang dikorbankan (scariffed) atau dilepaskan (forgone) untuk mencapai tujuan tertentu. Dari definisi diatas dapat disimpulkan bahwa biaya merupakan sumber ekonomi yang dikorbankan dan dapat diukur dalam satuan uang untuk memperoleh barang atau jasa yang berguna untuk masa kini maupun masa depan.

Menurut (Mulyadi, 2015) biaya produksi merupakan biaya-biaya yang dikeluarkan dalam pengolohan bahan baku menjadi produk. Biaya produksi membentuk kos produksi, yang digunakan untuk menghitung kos produk jadi dan kos produk yang pada akhir periode akuntansi masih dalam proses. Adapun beberapa tujuan biaya produksi adalah untuk menentukan jumlah biaya produksi secara tepat, untuk membantu manajemen mengadakan pengendalian biaya yang tepat, untuk membantu manajemen dalam pengambilan keputusan jangka pendek dan untuk menentukan harga jual sebuah produk.

Adapun indikator biaya produksi yang dirumuskan sebagai berikut:

$$
\text { Biaya Produksi }=\text { Biaya Bahan Baku }+ \text { Biaya Tenaga Kerja }+ \text { Biaya Overhead }
$$

Penelitian terdahulu mengenai pengaruh Biaya Produksi terhadap Laba Bersih yang dilakukan oleh (Putra, 2018) yang menghasilkan kesimpulan bahwa 
biaya produksi berpengaruh terhadap laba bersih. Namun penelitian yang dilakukan oleh (Susilawati, 2019) menunjukkan bahwa biaya produksi tidak berpengaruh terhadap laba bersih.

Biaya operasional merupakan biaya yang dikeluarkan untuk melaksanakan aktivitas dalam suatu proses produksi yang memiliki sifat habis pakai dalam jangka waktu yang relatif singkat (kurang dari satu tahun). (Rudianto, 2009) menyatakan bahwa biaya operasional terdiri dari dua bagian, yaitu biaya pemasaran dan biaya administrasi umum. Adapun indikator biaya operasional yang dirumuskan sebagai berikut: Biaya Operasional $=$ Biaya Penjualan + Biaya Administrasi dan Umum.

Penelitian terdahulu mengenai pengaruh Biaya Operasional terhadap Laba Bersih yang dilakukan oleh (Manda, 2018) yang menghasilkan kesimpulan bahwa biaya operasional berpengaruh terhadap laba bersih. Berbeda dengan penelitian yang dilakukan oleh (Ferliyanti \& Rostiati, 2019) yang menghasilkan kesimpulan bahwa biaya operasional tidak berpengaruh terhadap laba bersih.

Penjualan merupakan hasil akhir yang dicapai perusahaan dari hasil penjualan produk yang dihasilkan oleh perusahaan tersebut. Menurut (Marbun, 2003) penjualan adalah total barang yang terjual oleh perusahaan dalam jangka waktu tertentu.

Penjualan merupakan faktor penentu atas pencapaian tujuan perusahaan yang optimal, sehingga perkembangan perusahaan dapat terus meningkat sesuai dengan yang diharapkan. Semakin besar jumlah penjualan yang dihasilkan perusahaan, semakin besar kemungkinan laba yang akan dihasilkan perusahaan. 
Dari definisi tersebut dapat disimpulkan bahwa penjualan merupakan total yang dihasilkan dari kegiatan penjualan barang.

Aktivitas penjualan banyak dipengaruhi oleh faktor yang dapat meningkatkan aktivitas perusahaan, oleh karena itu manajer perlu memperhatikan faktor-faktor yang mempengaruhi penjualan. Menurut (Swasta, 2005) faktorfaktor yang mempengaruhi penjualan ada empat, yaitu: kondisi dan kemampuan penjual, kondisi pasar, modal, dan kondisi organisasi perusahaan. Menurut (Effendi, 2009) faktor yang sangat penting dalam mempengaruhi penjualan adalah saluran distribusi yang bertujuan untuk melihat peluang pasar yang dapat memberikan laba yang maksimum. Penjualan Bersih $=$ Penjualan Barang/Jasa Pemotongan Penjualan - Retur. Penelitian terdahulu mengenai pengaruh Penjualan terhadap Laba Bersih yang dilakukan oleh (Sasongko, 2014) yang mengemukakan bahwa penjualan berpengaruh terhadap laba bersih. Namun penelitian yang dilakukan oleh (Zahara \& Zannati, 2018) menunjukkan bahwa penjualan tidak berpengaruh terhadap laba bersih.

Menurut (Kasmir, 2014) laba bersih adalah laba yang telah dikurangi biaya-biaya yang menjadi beban perusahaan dalam satu periode tertentu termasuk pajak. Menurut (Chariri \& Gozali, 2003) mengutarakan bahwa tujuan pelaporan laba adalah sebagai indikator efisiensi penggunaan dana yang tertahan dalam perusahaan yang diwujudkan dalam tingkat kembalian, sebagai pengukuran prestasi atas kinerja badan usaha dan manajemen, sebagai kompensasi dan pembagian bonus, sebagai alat motivasi manajemen dalam pengendalian perusahaan, sebagai dasar bentuk kenaikan kemakmuran, dan sebagai dasar 
pembagian deviden. Dalam menilai keberhasilan suatu perusahaan dapat dilihat dari perolehan laba yang optimal. Laba yang diperoleh perusahaan dapat digunakan untuk berbagai kepentingan, salah satunya adalah digunakan untuk meningkatkan kesejahteraan perusahaan tersebut. Dengan itu perusahaan dituntut untuk meningkatkan kinerja, sehingga mampu mencapai target yang diinginkan.

$$
\text { Laba Bersih }=\text { Pendapatan }- \text { Beban }- \text { Pajak }
$$

Dari informasi tersebut peneliti menemukan adanya inkonsistensi hasil penelitian mengenai pengaruh biaya produksi, biaya operasional dan penjualan terhadap laba bersih. Atas dasar tersebut, peneliti menggunakan ketiga variabel tersebut dalam penelitian ini. Maka peneliti tertarik untuk membuat penelitian yang berjudul "Faktor-faktor yang Mempengaruhi Laba Bersih pada Perusahaan Industri Rokok yang Terdaftar di BEI Periode 2009-2019)””.

\section{METODE PENELITIAN}

Metode yang digunakan dalam penelitian ini yaitu verifikatif dan deskriptif. Penelitian dilakukan pada Perusahaan Industri Rokok yang terdaftar di Bursa Efek Indonesia periode tahun 2009-2019. Metode pengumpulan data yaitu dengan menggunakan metode dokumentasi dan studi pustaka. Jenis data adalah data sekunder laporan tahunan 2009-2019 yang diperoleh dari website resmi masing-masing perusahaan rokok yaitu (PT Gudang Garam Tbk, n.d.), (PT HM Sampoerna, n.d.) dan (PT Wismilak Inti Makmur, n.d.) serta dari website BEI (Bursa Efek Indonesia, n.d.). 
Teknik pengumpulan sampel menggunakan teknik purposive sampling, dimana sampel yang diambil berdasarkan kriteria-kriteria yang telah ditentukan. Dalam penelitian ini sampel yang diambil sebanyak 3 perusahaan rokok dengan periode penelitian 2009-2019.

Hipotesis diuji dengan analisis regresi linier berganda dengan bantuan SPSS 16. Sehingga didapat persamaan sebagai berikut:

$$
\mathrm{Y}=\alpha+\beta_{1} \mathrm{X}_{1}+\beta_{2} \mathrm{X}_{2}+\beta_{3} \mathrm{X}_{3}+\mathrm{e}
$$

Notasi:

$$
\begin{array}{ll}
\mathrm{Y} & =\text { Laba Bersih } \\
\alpha & =\text { Konstanta } \\
\beta & =\text { Koefisien Regresi } \\
\mathrm{X}_{1} & =\text { Biaya Produksi } \\
\mathrm{X}_{2} & =\text { Biaya Operasional } \\
\mathrm{X}_{3} & =\text { Penjualan } \\
\mathrm{e} & =\text { Error term }
\end{array}
$$

\section{HASIL DAN PEMBAHASAN}

Analisis statistik deskriptif digunakan untuk memberikan gambaran mengenai masing-masing variabel penelitian. Berikut tabel 1 hasil uji analisis deskriptif :

Tabel 1.

Hasil Analisis Statistik Deskriptif

\begin{tabular}{lcllll}
\hline \multicolumn{1}{c}{ Variabel } & N & Minimum & Maximum & Mean & $\begin{array}{c}\text { Std. } \\
\text { Deviation }\end{array}$ \\
\hline Laba Bersih & 33 & 17.872 & 13.721 .513 & $5.469 .961,61$ & $4.717 .241,42$ \\
Biaya Produksi & 33 & 313.079 & 19.649 .026 & $9.354 .554,30$ & $7.106 .812,91$ \\
Biaya & 33 & 113.977 & 9.045 .894 & $3.926 .145,27$ & $3.110 .612,26$ \\
Operasional & & & & & \\
Penjualan & 33 & 464.865 & 110.523 .819 & $48.075 .942,15$ & $39.171 .743,49$ \\
\hline Sumber $:$ data diolah peneliti, 2020 & & &
\end{tabular}

Nilai minimum laba bersih sebesar 17.872 yang artinya laba bersih terendah yang didapat sebesar 17.872 dari total laba bersih yang dimilikinya. Nilai 
maksimum 13.721.513 artinya laba bersih tertinggi yang didapat dari total laba bersih yang dimilikinya. Nilai rata-rata (mean) sebesar 5.469.961,61 dan nilai standar deviasi sebesar 4.717.241,420. Nilai standar deviasi lebih rendah dari nilai rata-rata, ini menunjukan bahwa hasil yang baik, karena standar deviasi merupakan cerminan dari deviasi yang rendah, artinya penyebaran data menunjukan kondisi normal.

Nilai minimum biaya produksi sebesar 313.079 yang artinya laba bersih terendah yang didapat sebesar 313.079 dari total laba bersih yang dimilikinya. Nilai maksimum 19.649.026 artinya laba bersih tertinggi yang didapat dari total laba bersih yang dimilikinya. Nilai rata-rata (mean) sebesar 9.354.554,30 dan nilai standar deviasi sebesar 7.106.812,915. Nilai standar deviasi lebih rendah dari nilai rata-rata, ini menunjukan bahwa hasil yang baik, karena standar deviasi merupakan cerminan dari deviasi yang rendah, artinya penyebaran data menunjukan kondisi normal.

Nilai minimum biaya operasional sebesar 113.977 yang artinya laba bersih terendah yang didapat sebesar 113.977 dari total laba bersih yang dimilikinya. Nilai maksimum 9.045.894 artinya laba bersih tertinggi yang didapat dari total laba bersih yang dimilikinya. Nilai rata-rata (mean) sebesar 3.926.145,27 dan nilai standar deviasi sebesar 3.110.612,261. Nilai standar deviasi lebih rendah dari nilai rata-rata, ini menunjukan bahwa hasil yang baik, karena standar deviasi merupakan cerminan dari deviasi yang rendah, artinya penyebaran data menunjukan kondisi normal. 
Nilai minimum penjualan sebesar 464.865 yang artinya laba bersih terendah yang didapat sebesar 464.865 dari total laba bersih yang dimilikinya. Nilai maksimum $110.523,819$ artinya laba bersih tertinggi yang didapat dari total laba bersih yang dimilikinya. Nilai rata-rata (mean) sebesar 48.075.942,15 dan nilai standar deviasi sebesar 39.171.743,491. Nilai standar deviasi lebih rendah dari nilai rata-rata, ini menunjukan bahwa hasil yang baik, karena standar deviasi merupakan cerminan dari deviasi yang rendah, artinya penyebaran data menunjukan kondisi normal.

Uji Normalitas Data ini dilakukan untuk mengetahui apakah data yang digunakan dalam penelitian ini berdistribusi normal atau tidak, karena salah satu syarat sebelum melakukan Analisis Regresi Linear Berganda yaitu data yang digunakan harus terbebas dari uji normalitas data (data berdistribusi normal). Pengujian Normalitas data dalam penelitian ini yaitu menggunakan KolmogorovSmirnov yang terdapat dalam software SPSS. Data dikatakan berdistribusi normal apabila nilai rasidualnya lebih besar dari $5 \%$ atau 0,05 . Berdasarkan hasil olah data bantuan software SPSS 16 dalam uji normalitas data, maka dapat diperoleh hasil sebagai berikut :

Tabel 2.

\section{Hasil Uji Normalitas}

\begin{tabular}{lr}
\hline & Unstandardized Residual \\
\hline $\mathrm{N}$ & 33 \\
Kolmogorov-Smirnov Z & 1,158 \\
Asymp. Sig. (2-tailed) & 0,137 \\
\hline Sumber: Data diolah oleh peneliti, 2020. &
\end{tabular}


Uji Multikolinearitas memiliki tujuan untuk mengetahui apakah moel regresi mempunyai korelasi antar variabel dependen. Melihat ada tidaknya multikolnieritas dalam model regresi dilihat dari nilai tolerance dan lawannya variance inflation factor (VIF). Adapun batas umum untuk menunjukan adanya multikolnieritas jika nilai VIF > 10,00 maka tidak terjadi multikolnieritas dan jika nilai VIF nya > 10,00 maka terjadi multikolnieritas. Pada tabel 3, nilai VIF untuk variabel biaya produksi, biaya operasional dan penjualan berada kisaran 9,246 sampai dengan 9,605 yang artinya nilai kurang dari 10. Maka dapat disimpulkan model regresi bebas atau tidak terjadi multikolnieritas antar variabel independen.

Tabel 3. Hasil Uji Multikolinieritas

\begin{tabular}{|c|c|c|c|}
\hline \multirow{2}{*}{ Variabel } & \multicolumn{2}{|c|}{ Collinearity Statistics } & \multirow{2}{*}{ Keterangan } \\
\hline & Tolerance & VIF & \\
\hline Biaya Produksi & 0,106 & 9,457 & Tidak terjadi Multikolnieritas \\
\hline Biaya Operasional & 0,104 & 9,605 & Tidak terjadi Multikolnieritas \\
\hline Penjualan & 0,108 & 9,246 & Tidak terjadi Multikolnieritas \\
\hline
\end{tabular}

Sumber: Data diolah oleh peneliti, 2020.

Uji Glejser digunakan agar bisa mengetahui apakah pola variabel gangguan mengandung heteroskedastisitas atau tidak. Diketahui nilai signifikan pada variabel Biaya Produksi sebesar 0,180>0,05, variabel Biaya Operasional sebesar 0,207 > 0,05 dan variabel Penjualan sebesar 0,176 > 0,05. Sehingga dapat disimpulkan model regresi dalam penelitian ini bebas dari heteroskedastisitas.

Uji Heteroskedastisitas memiliki tujuan untuk mengetahui apakah dalam model regresi linear berganda terdapat ketidaksamaan variance dari residual satu pengamatan ke pengamatan lain. Uji Heteroskedastisitas ini menggunakan Uji Glejser sebagai berikut : 
Tabel 4.

Hasil Uji Heteroskedastisitas

\begin{tabular}{|c|c|c|c|c|c|}
\hline \multirow{2}{*}{ Variabel } & \multicolumn{2}{|c|}{$\begin{array}{c}\text { Unstandardized } \\
\text { Coefficients }\end{array}$} & \multirow{2}{*}{$\begin{array}{c}\begin{array}{c}\text { Standardized } \\
\text { Coefficients }\end{array} \\
\text { Beta }\end{array}$} & \multirow{2}{*}{$\mathbf{t}$} & \multirow{2}{*}{ Sig. } \\
\hline & B & Std. Error & & & \\
\hline Biaya Produksi &, 376 & ,095 & 247 & 2,511 & 0,180 \\
\hline Biaya Operasional &, 813 & ,103 &, 100 & 1,292 & 0,207 \\
\hline Penjualan &, 343 & ,090 &, 131 & 2,623 & 0,176 \\
\hline
\end{tabular}

Uji Autokorelasi memiliki tujuan untuk mengetahui apakah terdapat korelasi antara kesalahan pengganggu (variabel eror) pada periode $\mathrm{t}$ dengan periode t-1 pada periode sebelumnya pada model regresi linear berganda. Uji Autokorelasi dalam penelitian ini menggunakan Durbin-Watson yang terdapat dalam software SPSS.

Tabel 4.

Hasil Uji Autokorelasi

\begin{tabular}{ccccc}
\hline Model & R & R Square & $\begin{array}{c}\text { Durbin- } \\
\text { Watson }\end{array}$ & Keterangan \\
\hline 1 &, 975 & 0,95 & 1,931 & Tidak terjadi autokorelasi \\
\hline
\end{tabular}

Sumber: hasil diolah oleh peneliti, 2020.

Tabel 5.

Hasil Uji Regresi Linier Berganda

\begin{tabular}{ccccc}
\hline \multirow{2}{*}{ Variabel } & \multicolumn{2}{c}{$\begin{array}{c}\text { Unstandardized } \\
\text { Coefficients }\end{array}$} & \multirow{2}{*}{ T } & Sig. \\
\cline { 2 - 3 } & B & Std. Error & & \\
\hline (Constant) &, 324 &, 556 & 5,984 &, 000 \\
Biaya Produksi &, 376 &, 095 & 2,511 & 0,180 \\
Biaya Operasional &, 813 &, 103 & 1,292 & 0,207 \\
Penjualan &, 343 &, 090 & 2,623 & 0,176 \\
\hline Sumber: Data diolah peneliti, 2020. & & &
\end{tabular}

Diperoleh hasil nilai DW sebesar 1,931 dimana nilai DW tersebut berada diantara -2 sampai dengan +2 , berdasarkan Tabel 4 maka dapat disimpulkan data 
dalam model penelitian ini tidak mengandung autokorelasi.

Hasil persamaan analisis regresi linear berganda sebagai berikut :

Laba Bersih $(\mathrm{Y})=0,324+0,376$ Biaya Produksi + 0,813 Biaya Operasional + 0,343 Penjualan

Berdasarkan dari hasil persamaan regresi tersebut, maka dapat diperoleh nilai konstanta sebesar 0,324. Sehingga apabila variabel Laba Bersih (Y) tidak dipengaruhi oleh ketiga variabel independent yaitu Biaya Produksi, Biaya Operasional dan Penjualan nilai nya sama dengan 0, maka rata-rata Laba Bersih akan bernilai sebesar 0,324. Nilai koefisien regresi pada variabel-variabel bebasnya menggambarkan apabila diperkirakan variabel bebasnya naik satu unit dan nilai variabel bebas lainnya diperkirakan konstan atau sama dengan nol, maka nilai variabel terikat diperkirakan bisa naik atau turun sesuai dengan tanda koefisien regresi variabel bebasnya.

Koefisien regresi untuk variabel $\mathrm{X}_{1}$ yaitu Biaya Produksi bernilai positif, artinya adanya hubungan searah antara Biaya Produksi $\left(\mathrm{X}_{1}\right)$ dengan Laba Bersih (Y). Koefisien regresi variabel $\mathrm{X}_{1}$ sebesar 0,376 berarti bahwa setiap pertambahan Biaya Produksi $\left(\mathrm{X}_{1}\right)$ sebesar satu akan menyebabkan menurunnya Laba Bersih (Y) sebesar 0,376. Koefisien regresi untuk variabel $\mathrm{X}_{2}$ yaitu Biaya Operasional bernilai positif, artinya adanya hubungan yang searah antara Biaya Operasional $\left(\mathrm{X}_{2}\right)$ dengan Laba Bersih(Y). Koefisien regresi variabel $\mathrm{X}_{2}$ sebesar 0,813 berarti bahwa setiap pertambahan Biaya Operasional $\left(\mathrm{X}_{2}\right)$ sebesar satu akan menyebabkan meningkatnya Laba Bersih (Y) sebesar 0,813. Koefisien regresi untuk variabel $\mathrm{X}_{3}$ yaitu Penjualan bernilai positif, artinya adanya hubungan yang searah antara Penjualan $\left(\mathrm{X}_{3}\right)$ dengan Laba Bersih $(\mathrm{Y})$. Koefisien regresi variabel 
$\mathrm{X}_{3}$ sebesar 0,343 berarti bahwa setiap pertambahan Penjualan $\left(\mathrm{X}_{3}\right)$ sebesar satu akan menyebabkan meningkatnya Laba Bersih (Y) sebesar 0,343.

Berdasarkan hasil pengujian dalam software SPSS untuk variabel $\mathrm{X}_{1}$ biaya produksi diperoleh nilai thitung sebesar 2,511. Jika dibandingkan dengan nilai $t_{\text {tabel }}$ yaitu sebesar 2,04523 maka $t_{\text {hitung }}>t_{\text {tabel. }}$. Sehingga dapat disimpulkan $\mathrm{H}_{0}$ ditolak dan $\mathrm{H}_{\mathrm{a}}$ diterima. Dengan demikian, dapat disimpulkan secara parsial bahwa Biaya Produksi berpengaruh terhadap Laba Bersih.

Berdasarkan hasil pengujian dalam software SPSS untuk variabel $\mathrm{X}_{2}$ biaya operasional diperoleh nilai thitung sebesar 1,292. Jika dibandingkan dengan nilai $\mathrm{t}_{\text {tabel }}$ yaitu sebesar 2,04523 maka $\mathrm{t}_{\text {hitung }}<\mathrm{t}_{\text {tabel. }}$. Sehingga dapat disimpulkan $\mathrm{H}_{0}$ diterima dan $\mathrm{H}_{\mathrm{a}}$ ditolak. Dengan demikian, dapat disimpulkan secara parsial bahwa Biaya Operasional tidak berpengaruh terhadap Laba Bersih.

Berdasarkan hasil pengujian dalam software SPSS untuk variabel $\mathrm{X}_{3}$ penjualan diperoleh nilai $t_{\text {hitung }}$ sebesar 2,623. Jika dibandingkan dengan nilai $t_{\text {tabel }}$ yaitu sebesar 2,04523 maka $t_{\text {hitung }}>\mathrm{t}_{\text {tabel. }}$. Sehingga dapat disimpulkan $\mathrm{H}_{0}$ ditolak dan $\mathrm{H}_{\mathrm{a}}$ diterima. Dengan demikian, dapat disimpulkan secara parsial bahwa Penjualan berpengaruh terhadap Laba Bersih. Pengujian Hipotesis secara Simultan bertujuan untuk mengetahui apakah variabel-variabel independent berpengaruh secara simultan (bersama-sama) terhadap variabel dependent.

Tabel 6.

\section{Hasil Uji Simultan}

\begin{tabular}{|c|c|c|c|}
\hline Model & $\mathbf{F}$ & Sig. & Keterangan \\
\hline 1 Regression & 182,62 &, $000^{\mathrm{a}}$ & Berpengaruh \\
\hline
\end{tabular}

Sumber: Data diolah oleh peneliti, 2020. 
Dalam pengaruh simultan antara Biaya Produksi, Biaya Operasional, dan Penjualan terhadap Laba Bersih ditentukan dengan tingkat signifikan 5\% $(0,05)$ dan derajat kebebasan $\mathrm{df}_{1}\left(\right.$ variabel-1) $=3$ dan $\mathrm{df}_{2}(\mathrm{n}-\mathrm{k}-1)=29$ (33-3-1). Dari ketentuan tersebut maka Ftabel didapat $(3 ; 29)=2,93$. Berdasarkan hasil pengujian secara simultan, yaitu diperoleh nilai Fhitung sebesar 182,620 dan signifikansi 0,000 yang berarti menunjukkan nilai Fhitung > Ftabel yaitu 182,620 > 2,93 dengan nilai sig $0,000<0,05$ maka Ho ditolak dan Ha diterima. Dengan demikian dapat disimpulkan bahwa terdapat pengaruh secara simultan antara variabel independen yaitu Biaya Produksi, Biaya Operasional, dan Penjualan berpengaruh terhadap variabel dependen yaitu Laba Bersih.

Analisis Koefisiensi Determinasi digunakan untuk melihat seberapa besar variabel independen $(\mathrm{X})$ berpengaruh terhadap variabel dependen $(\mathrm{Y})$ yang dinyatakan dalam persentase. Semakin tinggi nilai koefisien determinasi maka semakin tinggi pula pengaruh independent terhadap variabel dependent.

Tabel 7.

Hasil Uji Koefisien Determinasi

\begin{tabular}{rrrrr}
\hline Model & R Square & $\begin{array}{c}\text { Adjusted R } \\
\text { Square }\end{array}$ & $\begin{array}{c}\text { Std. Error of the } \\
\text { Estimate }\end{array}$ \\
\hline 1 & 990 &, 945 & $1.111 .034,13$ \\
\hline
\end{tabular}

Sumber: Data diolah oleh peneliti, 2020.

Nilai koefisien determinasi atau Adjusted $R$ Square $\left(\mathrm{R}^{2}\right)$ sebesar 0,945 atau sebesar 94,5\%. Hal ini menunjukkan bahwa variabel yang di teliti yaitu Biaya Produksi, Biaya Operasional, dan Penjualan berpengaruh terhadap Laba Bersih sebesar 94,5\%. Sedangkan sisanya yaitu sebesar 5,5\% dipengaruhi oleh variabel lain yang belum diteliti dalam penelitian ini. 
Hasil analisis data membuktikan bahwa biaya produksi berpengaruh terhadap laba bersih periode 2009-2019. Dengan adanya peningkatan biaya produksi, akan berpengaruh pada jumlah produk yang dihasilkan juga meningkat sehingga produk yang tersedia untuk dijual juga bertambah. Hasilnya volume penjualan bertambah dan laba bersih juga mengalami peningkatan. Dengan kata lain, biaya produksi bertambah mengakibatkan bertambahnya pula laba bersih yang diperoleh perusahaan. Hasil penelitian ini juga didukung oleh teori (Carter, 2009) yang menyatakan bahwa tingkat laba yang diperoleh perusahaan dapat dipengaruhi oleh biaya produksi yang dikeluarkan.

Biaya produksi pada Perusahan Industri Rokok terdiri dari biaya bahan baku, biaya tenaga kerja langsung dan biaya overhead pabrik. Adapun metode penentuan biaya produksi pada Perusahaan Industri Rokok adalah berdasarkan variable costing. Seperti diketahui adanya peningkatan biaya produksi dapat menyebabkan penurunan pada laba perusahaan. Untuk itu perusahaan dapat melakukan efisien terhadap biaya produksi dengan cara meminimalkan pemborosan bahan baku, mengurangi biaya tenaga kerja, gunakan mesin dan peralatan dengan benar, mengurangi pemborosan dalam penggunaan modal kerja, dan hindari menyimpan persediaan.

Dengan melakukan langkah-langkah tersebut, maka perusahaan melakukan produksi dengan biaya yang minimal (relative, tergantung produk dan segmen pasar), dan perusahaan dapat menjual produk tersebut dengan harga yang tepat. Dengan efisiensi perusahaan juga akan mendapatkan beberapa hal antara lain yaitu bertambahnya konsumen yang membeli produk karena perusahaan dapat 
menetapkan harga produk yang tepat, kemampuan bersaing dengan perusahaan lain yang dimiliki produk sejenis, laba bersih yang diperoleh akan lebih besar karena dapat menekan biaya dengan mengurangi pengeluaran yang tidak perlu, dan ketika laba bersih suatu perusahaan meningkat maka akan menarik para investor untuk menanamkan modalnya.

Hasil analisis data membuktikan bahwa biaya operasional tidak berpengaruh terhadap laba bersih periode 2009-2019. Biaya operasional tidak memiliki pengaruh terhadap laba bersih, karena banyaknya biaya operasional yang dikeluarkan tidak akan mempengaruhi jumlah unit yang dijual. Hal ini diduga karena semakin banyaknya kegiatan yang dilakukan perusahaan sehingga menyebabkan tingginya pengeluaran biaya operasional. Serta faktor lain seperti kurangnya pengendalian yang terarah, dan kontrol pengeluaran biaya operasional yang tidak dilakukan dengan baik. Dengan demikian, hal tersebut memberikan dampak yang cukup membahayakan bagi perusahaan industri rokok, karena pengendalian biaya operasional yang kurang baik berakibat tingginya biaya operasional yang dikeluarkan, sehingga dikhawatirkan dapat menyebabkan kegagalan perusahaan dalam mencapai tujuannya. Semakin berkembangnya atau besarnya perusahaan maka secara otomatis akan semakin meningkat kegiatan operasional yang dilakukan oleh perusahaan. Semakin meningkatnya kegiatan perusahaan akan membuat biaya yang dikeluarkan untuk operasional perusahaan semakin meningkat atau tinggi. Oleh karena itu biaya ini tidak bisa ditiadakan namun yang bisa dilakukan adalah mengeluarkan biaya secara efektif dan efisien. Dengan demikian maka pemborosan biaya dapat dihindarkan dan laba bersih 
dapat ditingkatkan Hasil penelitian yang dilakukan ini sejalan dengan penelitian yang dilakukan oleh (Ferliyanti \& Rostiati, 2019) yang mengemukakan bahwa Biaya Operasional tidak berpengaruh terhadap Laba Bersih.

Hasil analisis data membuktikan bahwa penjualan berpengaruh terhadap laba bersih periode 2009-2019. Laba akan mengalami peningkatan jika ada peningkatan penjualan dan biaya produksi, artinya semakin besar biaya produksi yang dikeluarkan akan menambah jumlah produksi sehingga potensi penjualan akan menaikkan laba, tetapi jika peningkatan biaya produksi tidak diimbangi dengan peningkatan penjualan maka akan mengakibatkan perusahaan mengalami penurunan laba. Faktor utama yang mempengaruhi besar kecilnya laba adalah pendapatan, pendapatan dapat diperoleh dari hasil penjualan barang dagangan perusahaan.

Hasil penelitian yang dilakukan ini sejalan dengan penelitian yang dilakukan oleh (Putra, 2018) yang mengemukakan bahwa Penjualan berpengaruh terhadap Laba Bersih. Dikatakan bahwa untuk meningkatkan laba bersih, maka penjualan pada suatu perusahaan harus meningkat juga dan pengeluaran biaya harus efisien.

\section{SIMPULAN DAN SARAN}

Berdasarkan penelitian dan pembahasan yang dilakukan oleh peneliti, maka dapat diambil beberapa kesimpulan bahwa Biaya Produksi berpengaruh terhadap Laba Bersih, Biaya Operasional tidak berpengaruh terhadap Laba Bersih, Penjualan berpengaruh terhadap Laba Bersih, dan Biaya Produksi, Biaya Operasional, dan Penjualan berpengaruh secara simultan terhadap Laba Bersih. 
Saran untuk perusahaan untuk dapat memperoleh laba yang maksimal hendaknya perusahaan mengoptimalkan saham/obligasinya, perusahaan harus berupaya terus meningkatkan inovasi-inovasi dan meminimalkan biaya-biaya yang dikeluarkan, perusahaan harus lebih meningkatkan penjualan agar laba bersih yang didapat meningkat, dan perusahaan diharapkan dapat mempertahankan laba bersih yang sudah dicapai agar kegiatan operasional perusahaan tidak terganggu. Diharapkan untuk peneliti selanjutnya agar bisa meneliti faktor lain yang dapat mempengaruhi laba bersih pada perusahaan industri rokok yang terdaftar di BEI. Sehingga hasil penelitian selanjutnya dapat dibandingkan dengan hasil penelitian penulis. Disarankan juga untuk peneliti selanjutnya untuk menambah variabel independen dan periode penelitian sehingga jumlah sampel yang dilakukan pada penelitian selanjutnya akan bertambah, guna memperoleh hasil penelitian yang lebih signifikan serta menggunakan metode dan alat uji yang lebih lengkap dan akurat sehingga memperoleh kesimpulan yang lebih valid.

\section{REFERENSI}

Bursa Efek Indonesia. (n.d.). https://www.idx.co.id

Carter, K. W. (2009). Akuntansi Biaya (Keempat). Salemba Empat.

Chariri, A., \& Gozali, I. (2003). Teori Akuntansi. Badan Penerbit Universitas Diponegoro.

Effendi, M. A. (2009). The Power Good Corporate Govermance : Teori dan Implementasi. Salemba Empat.

Ferliyanti, H., \& Rostiati. (2019). Pengaruh Biaya Produksi, Biaya Operasional, dan Penjualan Terhadap Laba Bersih Pada Perusahaan Manufaktur yang Terdaftar di Bursa Efek Indonesia Tahun 2012-2016. AKRAB JUARA, 4 (1), $52-62$. 
Horngren, C. T. (2008). Akuntansi Biaya (ke 12). Erlanga.

Kasmir. (2014). Analisis Laporan Keungan. PT Raja Grafindo Persada.

Manda, G. S. (2018). Pengaruh Pendapatan dan Biaya Operasional terhadap Laba Bersih (studi kasus pada Perusahaan Manufaktur Sektor Industri Dasar dan Kimia yang terdaftar di BEI periode 2012-2016). Jurnal Ekonomi Dan Bisnis "E-Qien," 5 (1), 19-33.

Marbun, B. (2003). Kamus Manajemen. Pustaka Sinar Harapan.

Mulyadi. (2015). Akuntansi Biaya (kelima). UPP STIM YKPN.

PT Gudang Garam Tbk. (n.d.). https://www.gudanggaramtbk.com

PT HM Sampoerna. (n.d.). https://www.sampoerna.com

PT Wismilak Inti Makmur. (n.d.). https://www.wismilak.com

Putra, M. Z. P. (2018). Pengaruh Biaya Produksi dan Biaya Promosi Dalam Meningkatkan Volume Penjualan Terhadap Laba Bersih. Universitas Komputer Indonesia.

Rudianto. (2009). Pengantar Akuntansi. Erlanga.

Sasongko, S. N. (2014). Pengaruh Modal dan Volume Penjualan Terhadap Laba Bersih. Universitas Komputer Indonesia.

Susilawati, E. (2019). Pengaruh Biaya Produksi dan Biaya Promosi Terhadap Laba Bersih (Studi Perusahaan Rokok PT Gudang Garam Tbk yang Terdaftar di BEI Periode 2011-2017). Unnur, 2 (1), 25-39.

Swasta, B. (2005). Asas-asas Marketing. Liberty.

Zahara, A., \& Zannati, R. (2018). Pengaruh Total Hutang, Modal Kerja, dan Penjualan Terhadap Laba Bersih pada Perusahaan Sub Sektor Batu Bara Terdaftar di BEI. Jurnal Riset Manajemen Dan Bisnis (JRMB), 3, 155-164. 